\title{
PEMBELAJARAN TARI BAGI ANAK USIA DINI
}

\begin{abstract}
Ai Sutini ${ }^{1}$
ABSTRAK

Seni tidak dapat dipisahkan dengan kehidupan manusia, termasukbagi perkembangan anaku usia dini. Seni disamping mempunyai nilai estetis, juga dapat merangsang kreativitas anak. Pendidikan anak usia dini yang merupakan cikal bakal proses pendidikan bangsa berupaya mengembangkan potensi dalam berbagai aspek seperti kognitif, bahasa, seni, moral, agama, motorik, sosial emosional. Salah satu aspek perkembangan fisik yang perlu dikembangkan yaitu aspek motorik anak. Salah satu bentuk stimulus motorik anak adalah melalui pembelajaran seni tari, dimanaperkembangan motorik meliputi perkembangan motorik kasar dan motorik halus. Kemampuan motorik setiap anak berbada tergantung dari tingkat kematangan. Unsur dasar tari meliputi gerak, tenaga, ruang dan waktu, keempat unsur tersebut sangat mempengaruhi kreativitas anak dalam mengekspresikan geraknya.
\end{abstract}

\section{Kata Kunci : Pendidikan anak usia dini, pembelajaran tari dan motorik anak.}

\section{A. Pendahuluan}

\section{Anak Usia Dini}

Menurut Undang-Undang No. 20 tahun 2003 tentang Sistem Pendidikan Nasional (UU Sisdiknas). Dalam bab 1 pasal 1 butir 14 dinyatakan bahwa : "Pendidikan Anak Usia Dini (PAUD) adalah suatu upaya pembinaan yang ditujukan anak sejak lahir sampai enam tahun yang dilakukan melalui pemberian rangsangan pendidikan untuk membantu pertumbuhan dan perkembangan jasmani dan rohani agar anak memiliki pendidikan lebih lanjut”.

Menurut kesepakatan UNESCO bahwa kelompok anak usia dini berada pada rentang 0-8 tahun. Perbedaan rentang usia antara UU RI No.20 tahun 2003 dengan UNESCO terletak pada prinsip karena perkembangan dan pertumbuhan usia 6-8 tahun merupakan usia transisi yang masih memerlukan pendampingan kearah yang lebih mandiri, baik dilihat dari segi fisik, mental, social emosional maupun intelektual.

Pendidikan anak usia dini merupakan salah satu bentuk penyelenggaraan pendidikan yang menitikberatkan pada peletakan dasar kearah pertumbuhan dan perkembangan fisik (koordinasi motorik halus dan kasar), kecerdasan (daya pikir, daya cipta, kecerdasan emosi, kecerdasan spiritual), sosial emosional (sikap dan perilaku), bahasa dan komunikasi sesuai dengan karakteristik dan perkembangan anak. Menurut Yeti (2011) bahwa aspek-aspek perkembangan tersebut meliputi :

\footnotetext{
${ }^{1}$ Dosen PGPAUD UPI Kampus Cibiru
} 
a. Perkembangan fisik : pada dua tahun pertama perkembangan bayi secara fisik lebih pesat daripada periode masa kanak-kanak. Pada tahun pertama berat badan meningkat, dan memperoleh keterampilan mobilitas seperti merangkak, berdiri, berjalan. Tahun kedua saatnya menghaluskan keterampilan mobilitas. Perkembangan motorik berlangsung melalui perkembangan proximodistal (berpusat pada badan dan jari jemari) dan perkembangan cephalocaudal (berpusat pada bagian badan turum ke kaki). Pada usia 5 bulan dapat meraih mainan, usia 7 bulan sudah mulai tumbuh gigi. Pada masa prasekolah anak sudah mulai memperhalus motorik halus seperti mengembangkan keterampilan menggambar, memotong, mewarnai dan sebagainya. Usia 3 tahun sudah dapat bermain dengan membentuk balok. Usia 6 tahun sudah mulai kehilangan giginya. Menginjak usia sekolah dasar sudah memiliki kegiatan seperti olah raga, permainan.

b. Perkembangan kognitif : menurut Piaget tahap perkembangan kognitif anak sebagai tahap sensorimotorik karena bayi dapat mengetahui dan memahami sekelilingnya hanya dengan menggunakan indera dan tindakan refleks, seperti menghisap, menghirup, menggenggam. Pada usia 2-6 tahun mencapai tahap praoperasional, pada tahap ini sudah dapat menggunakan simbol dan dapat mempresentasikan ke dalam kata-kata dengan mengggunakan pikiran secara simbolis. Pada usia 6-8 tahun pindah ke tahap praoperasional kongkret. Penilaian anak tidak hanya berdasarkan persepsi melainkan operasi mental dan logis.

c. Perkembangan bahasa : pada usia dua tahun pertama bayi dan anak ada perkembangan dari prabahasa ke penggunaan bahasa primitif dapat menangis dengan tenang. Usia 10 bulan sudah mulai dengan intonasi bahasa, usia 18 bulan berkembang menjadi dua-tiga suku kata. Pada usia 2 tahun dapat menggunakan kalimat lebih panjang dan sempurna. Pada usia 3 tahun anak sudah mulai memahami dan menggunakan aturan percakapan. Usia prasekolah anak sudah dapat mengembangkan literasi (baca tulis) melalui pengembangan bahasa oral melalui buku-buku yang ada di lingkungannnya. Melalui interaksi percakapan dengan orang tua, pengasuh. Perkembangan bahasa tulis terjadi pada anak dimulai saat sekolah dasar.

d. Perkembangan sosial emosional : pada masa bayi terjadi ikatan emosional dengan orang tua. Pada usia 2 tahun pertama anak sudah ada tanda-tanda sosial dengan teman sebaya, anak sudah dapat berinteraksi dengan teman melalui permainan. Pada masa ini terjadi pengaruh sosial yang positif dan negatif. Pada usia 6-8 tahun anak mengalami transisi, karena anak menghadapi hal-hal penting dari segi sosial dan perkembangan emosionalnya.

Anak usia dini pada umumnya menyenangi aktivitas gerak yang berirama atau aktivitas ritmik dan dinamis. Mereka senang melakukan gerak-gerak yang mengikuti irama lagu atau bernyanyi. Kegiatan gerak tari dapat memberikan suatu dorongan atau rangsangan yang baik bagi anak-anak dalam proses membangun dan menemukan daya gerak mereka. Anak-anak perlu menemukan gerak asli sehingga 
dapat mengekspresikan dengan bantuan guru untuk berkreasi sesuai dengan keinginan jiwanya.

Usia dini berada pada masa peka, artinya anak mulai sensitif untuk menerima berbagai upaya perkembangan menyangkut seluruh potensi anak. Seperti yang dikemukakan oleh Samsudin (2008:1) adalah “ Masa peka merupakan masa terjadinya pematangan fungsi-fungsi fisik dan psikis yang siap merespons stimulus yang diberikan oleh lingkungan.” Usia emas dalam perkembangan motorik adalah middle childhood atau masa anak-anak. Pada anak usia dini, kesehatan fisik mulai stabil dan perkembangan fisik anak menjadi maksimal dari usia sebelumnya.

Perkembangan motorik meliputi perkembangan motorik kasar dan motorik halus. Pada usia prasekolah gerakan-gerakan fisik yang dilakukan tidak hanya untuk mengembangkan fisik saja tetapi dapat berpengaruh positif terhadap rasa harga diri anak. Kurangnya keterampilan motorik halus yang anak kuasai akan berdampak terhadap rendahnya penerimaan diri anak, anak mudah frustasi, putus asa, dan akhirnya anak malas melakukan kegiatan-kegiatan lainnya. Hal senada diperkuat oleh pendapat Solehudin (2000:60) sebagai berikut:

Pertumbuhan fisik, anak usia ini masih perlu aktif melakukan berbagai aktivitas. Kebutuhan anak untuk melakukan berbagai aktivitas ini sangat diperlukan baik bagi pengembangan otot-otot kecil maupun otot-otot besar. Pengembangan otot-otot kecil ini terutama diperlukan anak untuk menguasai keterampilan dasar akademik, seperti untuk belajar menggambar dan menulis.

Kemampuan motorik anak berbeda-beda, ada yang lambat dan ada pula yang sesuai dengan perkembangan tergantung pada kematangan anak. Oleh karena itu sejak usia dini aspek pengembangan motorik anak dalam bentuk kegiatan yang menyenangkan dapat menstimulus perkembangan motorik anak secara maksimal khususnya perkembangan motorik halus anak. Kegiatan tersebut dilakukan dengan cara bermain, gerakan motorik anak akan berdampak positif pada aspek perkembangan yang lainnya. Menurut Ghazali (Abidin,2009:1) bahwa 'bermain mempengaruhi perkembangan dan pertumbuhan anak baik secara fisik-motorik maupun secara psikologi atau kejiwaannya serta perkembangan intelejensinya.

Pada usia 5 atau 6 tahun koordinasi gerakan motorik halus berkembang pesat. Pada masa ini anak telah mampu mengkoordinasikan gerakan visual motorik, seperti mengkoordinasikan gerakan mata dengan tangan, lengan, dan tubuh secara bersamaan, antara lain dapat dilihat pada waktu anak menulis atau menggambar.

Perkembangan motorik yang terlambat berarti perkembangan motorik yang berada di bawah normal umur anak, akibatnya pada umur tertentu anak tidak menguasai tugas perkembangan yang diharapkan kelompok seusianya.

Anak-anak yang mengalami keterlambatan dalam perkembangan motorik halus mengalami kesulitan untuk mengkoordinasikan gerakan tangan dan jari jemarinya secara fleksibel. Adapun beberapa faktor yang menyebabkan keterlambatan perkembangan kemampuan motorik halus anak misalnya kurangnya kesempatan untuk melakukan eksplorasi terhadap lingkungan sejak bayi, tidak 
membiasakan untuk mengerjakan aktivitas sendiri sehingga anak terbiasa selalu dibantu untuk memenuhi kebutuhannya. Misalnya kebiasaan menggunakan baju dengan mengkancingkan baju sendiri, menggunakan sepatu dengan tali sepatu sendiri dan sebagainya. Hal tersebut akan menjadi kebiasaan sendiri dan secara tidak langsung motorik halus anak terangsang. Anak-anak yang kurang menggunakan waktunya melakukan kegiatan yang memakai motorik halus bisa menyebabkan kurang berkembangya otot-otot halus pada tangan.

\section{B. Pembelajaran Seni}

Pendidikan seni merupakan yang paling efektif untuk meningkatkan kreativitas, disamping itu pendidikan seni menjadi sarana pendidikan afektif dalam kerangka mengakomodasi emosi dan ekspresi anak. Ada dua macam konsep pendidikan seni yakni konsep pertama seni dalam pendidikan maksudnya sebagai proses enkulturasi (proses pembudayaan yang dilakukan dengan upaya mewariskan atau menanamkan nilai-nilai dari generasi tua ke generasi berikutnya). Dengan demikian pendekatan seni dalam pendidikan merupakan upaya pendidik untuk mengembangkan dan melestarikan berbagai jenis kesenian yang ada kepada peserta didik. Sedangkan konsep kedua pendidikan melalui seni, maksudnya pendidikan seni berkewajiban mengarahkan ketercapaian tujuan pendidikan secara umum yang memberikan keseimbangan rasional, emosional, intelektualitas. Menurut Syafii (2004:1.13) menyebutkan fungsi pendidikan seni adalah (1) pendidikan seni sebagai media ekspresi,(2) pendidikan seni sebagai media komunikasi,(3) pendidikan seni sebagai media bermain,(4) pendidikan seni sebagai media pengembangan bakat dan (5) pendidikan seni sebagai media kreativitas.

Pembelajaran seni yang ideal untuk anak-anak terutama anak usia dini harus sesuai dengan karakteriktik anak. Adapun ruang lingkup pembelajaran seni meliputi kajian :

a. Mainan, hiasan, benda pakai

b. Gambar, cetak, bentuk dan penataan

c. Kepekaan unsur-unsur dan kreativitas musik

d. Wiraga, wirahma, wirasa.

\section{Pembelajaran Tari}

\section{Pengertian Tari}

Menurut Lincoln Kirstein, kata tari dalam Bahasa Inggris terkait pada Bahasa Prancis danse yang keduanya dianggap berakar dari Bahasa Jerman Kuno donson yang berari regangan (stretch) atau tarikan (drag).

Tari sebagai bentuk seni merupakan aktivitas khusus yang bukan hanya sekedar ungkapan gerak yang emosional atau mengungkapkan perasaan dalam wujud gerak tanpa arah dan tujuan, akan tetapi merupakan stimulus yang mempengaruhi organ syaraf kinestetik manusia sebagai sebuah perwujudan pola-pola yang bersifat konstruktif. 
Keterampilan gerak dasar tari merupakan proses belajar anak agar bisa konsentrasi, aktif, ekspresif dan kreatif melalui gerakan-gerakan secara simbolik. Tari pada anak usia dini disesuaikan dengan kemampuan gerak yang dapat dilakukan sesuai dengan fase perkembangan kinestetiknya (psikomotornya).

Menurut Sach (Rachmi, 2008: 6.4) bahwa 'tari adalah gerak tubuh yang ritmis'. Senada dengan Sach, Soedarsono mengemukakan bahwa 'tari adalah desakan perasaan manusia tentang "sesuatu” yang disalurkan melalui gerak-gerak ritmis yang indah’ (Rachmi, 2008: 6.5). Sedangkan Haukin (Admin, 2010) menyatakan bahwa 'tari adalah ekspresi jiwa manusia yang diubah oleh imajinasi dan diberi bentuk melalui media gerak sehingga menjadi bentuk gerak yang simbolis dan sebagai ungkapan si pencipta'. Hal ini dapat dimaksudkan bahwa tari merupakan penggabungan antara olah gerak tubuh yang memiliki makna, indah dan ekspresi yang diungkapkan oleh orang yang menampilkannya, baik tari yang diiringi dengan irama maupun tidak.

Gerak tari dapat membantu meningkatkan kecerdasan kinestetik bagi anak usia dini, dimana gerak tari dapat memberikan penguatan konsentrasi, keluwesan serta keindahan gerak, tidak hanya dalam penguasaan kinestetik (psikomotor) saja melainkan dapat memberikan dan peluang keterampilan gerak tari yang diperoleh.

Gerak dasar tari dapat didefinisikan sebagai gerakan yang bersifat jasmaniah yang terdiri dari adanya ide, gerak dan irama sehingga menghasilkan makna.

Tari adalah jenis kesenian yang terkait langsung dengan gerak tubuh manusia, tubuh adalah alatnya dan gerak tubuh sebagai medianya. Gerak tubuh yang dapat dijadikan media dalam tari yaitu dimulai dari gerakan kepala sampai ujung kaki melalui gerakan yang halus (fine motor) atau gerakan kasar (gross motor) (Rachmi, 2008: 6.3).

Tari merupakan sebuah seni yang mempunyai konsep dan koreografi yang bersifat kreatif. Pengertian tari yang paling sederhana dikemukakan oleh tokoh sejarah musik dan tari dari luar dan dalam negeri seperti yang dikemukakan Hidayat (2006: 22-24) berikut ini.

a. Menurut Curt Sach “ tari adalah gerakan yang ritmis (dance is rhythmic motion), pengertian ini mengisyaratkan bahwa gerakan itu lebih besar berkaitan dengan pola waktunya sebagai sebuah proses terbentuknya rangkaian tubuh yang bermakna.

b. Menurut Dr. J. Verkuyl menekankan pada gerak anggota badan (tubuh), keteraturan dan irama. "Tari adalah gerak-gerik tubuh dan anggota-anggotanya yang diatur sedemikian rupa sehingga berirama”.

c. Menurut Crawiey, tari adalah pernyataan gerak interaktif dari urat mengenai suatu perasaan. Pengertian tersebut menunjukan bahwa tari sangat berurusan dengan perasaan, sensitivitas jiwa yang reaksional dengan menanggapi suatu stimulus dari luar atau reaksi spontan dari dalam diri manusia.

d. Menurut Wisnoe Wardana salah satu tokoh tari modern Indonesia, tari adalah kerja rasa dari manusia yang penyalurannya melewati urat-urat. Pemahaman 
tentang gerak dan didalamnya secara implicit terdiri dari otot dan atau urat tubuh yang bersifat teknis.

e. Menurut RM. Soedarsono dalam bukunya Djawa dan Bali; Dua Pusat Perkembangan Dramatari Tradisional di Indonesia, tari adalah ekspresi jiwa manusia yang diungkapkan melalui gerak-gerak ritmis dan indah (Soedarsono, 1978:3).

f. Menurut Bagong Kusudiarjo, tari adalah keindahan bentuk dari anggota badan manusia yang bergerak, berirama dan berjiwa yan harmonis.

Tari merupakan sebuah seni kolektif karena didalamnya terdapat beberapa unsur, meliputi seni musik, seni sastra, seni rupa dan seni drama. Masing-masing bentuk seni mempunyai unsur dasar yang dapat memberikan penjelasan dan ketegasan lebih bermakna mengenai bentuk seni tersebut.

Begitu juga dengan seni tari unsur dasar tari didalamnya meliputi gerak, tenaga, ruang dan waktu, sehingga dari unsur-unsur tersebut dapat memberikan peluang untuk dapat mengekspresikan jiwanya kedalam bentuk tari.

a. Gerak

Adapun unsur-unsur dasar tari adalah :

Tari merupakan salah satu bentuk seni yang harus dinikmati secara visual, karena merupakan karya yang lihat dari aspek keindahan gerak yang indah. Gerakgerak tari tidak terlepas dari sentuhan pengalaman-pengalaman hidup manusia, namun demikian bukan berarti gerak tersebut gerak keseharian manusia akan tetapi sudah mengalami stilisasi dan distorsi melalui eksplorasi.

Ada dua jenis gerak dalam tari, yaitu : gerak murni dan gerak maknawi. Gerak murni adalah gerak yang tidak mempunyai makna tertentu seperti godeg dan ukel. Gerak maknawi adalah gerak yang mempunyai makna tertentu seperti sembah, nyawang.

Media utama dalam menari adalah gerak, sehingga gerak merupakan aspek pengungkapan jiwa seseorang. Gerak bisa dikenali lebih mendalam dan dapat dikembangkan. Ada lima macam gerakan dasar yang terdiri dari koordinasi tubuh, kelincahan, kekuatan, keseimbangan, serta koordinasi mata dengan tangan dan kaki (Gallahue, 1998:16).

Gerak atau lazimnya disebut kinestetik, menurut Gardner merupakan suatu kehidupan yang melibatkan perasaan berupa pemberian kesadaran atas posisi gerak dengan pengontrolan yang dilakukan oleh otak (Gardner, 1983:210). Seperti yang diungkapkan Montessori bahwa gerak tubuh membantu mengembangkan pikiran yang dalam hal ini semakin mengejawantahkan dalam gerakan dan aktivitas berikutnya.

\section{b. Tenaga}

Secara umum tenaga sangat dibutuhkan oleh manusia untuk memenuhi kebutuhan segala aktivitasnya. Dengan tenaga kita bisa membedakan mana gerak yang harus dilakukan dengan kuat, sedang, maupun lembut. Penggunaan tenaga 
disesuaikan dengan kebutuhan geraknya. Penggunaan tenaga dalam tari meliputi tiga aspek yaitu :

1) Intensitas yaitu banyak atau sedikit penggunaan tenaga yang dilakukan oleh penari

2) Aksen yaitu perubahan gerak dengan penggunaa secara kontras

3) Kualitas yaitu efek gerak yang diakibatkan oleh cara penggunaan atau penyaluran tenaga.

c. Ruang

Pengertian ruang dalam tari adalah tempat yang digunakan dalam kebutuhan gerak. Pengertian ruang secara umum dapat diartikan ke dalam dua hal, yakni :

1) Ruang sebagai tempat pentas yaitu tempat penari untuk melakukan gerakan sebagai wujud ruang secara visual.

2) Ruang gerak, yakni ruang yang diciptakan oleh penari untuk melakukan gerakan. Misalnya gerak yang kecil tidak memerlukan tempat yang luas, sedangkan gerak yang luas memerlukan tempat yang luas.

d. Waktu

Unsur waktu merupakan elemen yang sangat dibutuhkan, karena berhubungan dengan penggunaan unsur lainnya seperti gerak, tenaga dan ruang. Penggunaan waktu dalam gerak tari berkaitan dengan penyelesaian sebuah gerakan.

\section{Pembelajaran Tari Bagi Anak Usia Dini}

Tari dalam dimensi pendidikan akan memberi warna dan arah pada pembentukan pengetahuan, sikap dan keterampilan gerak. Hal ini disebabkan karena pembelajaran tari tidak hanya mengembangkan kompetensi motorik semata, akan tetapi kompetensi afektif dan kognitif. Ada empat fungsi pendidikan taripada anak usia dini. Purnomo (1993:30-31) mengemukakan keempat fungsi itu sebagai berikut: (1) mengembangkan kompetensi intelektual. Hal ini disebabkan pada saat menari anak harus mempu secara kognitif, yaitu untuk memahami, mengerti, mensintesa bahkan mengevaluasi gerak yang dilakukan. Sedangkan dari ranah afektif anak dituntut untuk mampu bersikap positif menerima estetika tari. Sementara dari ranah psikomotorik anak dituntut untuk mampu melakukan gerak secara terampil, tepat dengan irama yang mengiringinya;(2) wahana sosialisasi. Tari dalam dimensi pendidikan juga merupakan wahana sosialisasi bagi anak, terutama sewaktu menari dalam bentuk kelompok. Setiap anak dituntut untuk mampu bekerjasama. Hal ini diperlukan untuk memberi kekompakan gerak sewaktu menari. Sosialisasi melalui tari akan berdampak pada rasa percaya diri pada anak;(3) wahana cinta lingkungan. Selain mengembangkan kompetensi intelektual dan kompetensi bersosialisasi, tari pendidikan juga mampu mengembangkan cinta lingkungan pada anak. Ini dapat dilakukan dengan cara memberi pengertian tentang makna tari yang terkandung didalamnya. Dengan demikian anak tidak hanya hanya hapal dalam menari melainkan dapat menanamkan sejak dini untuk mencintai lingkungan alam sekitar;(4) pengembangan kreativitas. Pengembangan kreativitas ini dapat dilakukan 
dengan melakukan eksplorasi gerak yang dilakukan oleh anak. Melalui eksplorasi anak-anak dapat mencoba dan menemukan berbagai ragam gerak yang dikehendaki.

Kemampuan yang sangat mendasar dari fisik anak usia dini dapat dilihat dari kemampuan dalam melakukan gerakan keseimbangan, lokomotor, kecepatan, adanya perubahan ekspresi, teknik, bisa mengendalikan tubuh dan dapat melakukan gerak energik melalui koordinasi dengan anggota tubuh lainnya.

Berikut ini hal-hal yang harus diperhatikan dalam pembelajaran tari bagi anak usia dini, yaitu : (1) tari imitatif, dan (2) karakteristik gerak tari bagi anak usia dini.

Menurut Rachmi (2008:6.7) secara umum karakteristik gerak bagi anak usia dini, yaitu :

1) Menirukan

Dalam bermain anak-anak senang menirukan hal-hal yang diamatinya baik secara audio, visual maupun audio visual. Ia mulai menirukan berbagai aktion/gerakan sampai pada otot-ototnya demi menurut kata hatinya.

2) Manipulasi (perlakuan)

Anak-anak melakukan gerakan-gerakan secara spontan dari objek yang diamatinya sesuai dengan keinginannya ataupun terhadap gerakan-gerakan yang disukainya.

3) Bersahaja

Anak-anak dalam melakukan gerak dengan sangat sederhana dan tidak dibuatbuat atau apa adanya. Kesahajaan itulah yang dimiliki anak. Contohnya ketika anak usia dini mendengarkan musik, ia akan menggerak-gerakan bagian tubuhnya sesuai dengan keinginan hatinya.

\section{Kemampuan Motorik Anak}

Motorik adalah terjemahan dari kata motor yang menurut Gallahue (Samsudin, 2008:10) adalah 'suatu dasar biologi atau mekanika yang menyebabkan terjadinya suatu gerak.' Gerak yang dimaksud tersebut bukan hanya gerak yang berhubungan dengan kegiatan sehari-hari yaitu gerak anggota tubuh seperti tangan,kaki dan tungkai tetapi gerak yang dimaksud adalah gerak yang didalamnya melibatkan fungsi motorik seperti otak, saraf,otot dan rangka. Hal itu sejalan dengan pendapat Cratty (Samsudin, 2008:6) mengatakan bahwa perkembangan motorik berkaitan dengan kematangan mekanisme otot, syaraf yang memberikan penampilan progresif di dalam keterampilan motorik. Perkembangan motorik sangat dipengaruhi oleh organ dan fungsi sistem susunan saraf pusat atau otak karena sistem susunan saraf pusat ini sangat berperan penting dalam kemampuan motorik dan mengkoordinasikan setiap gerakan yang dilakukan anak. Semakin matangnya perkembangan sistem saraf otak anak yang mengatur otot memungkinkan berkembangnya kompetensi atau kemampuan motorik anak.

Perkembangan motorik meliputi perkembangan otot kasar dan otot halus. Otot kasar atau otot besar adalah otot-otot badan yang tersusun dari otot lurik yang berfungsi untuk melakukan gerakan dasar tubuh yang terkoordinasi oleh otak, seperti berlari, melompat, menendang, melempar, menarik sehingga gerak tersebut dikenal dengan 
istilah gerakan dasar. Perkembangan motorik berikutnya meliputi perkembangan halus yang berfungsi untuk melakukan gerakan-gerakan yang lebih spesifik seperti mengancing baju, mengikat tali sepatu, menggunting, merangkai dan sebagainya.

Dalam perkembangan motorik anak meliputi motorik kasar dan motorik halus. Menurut Pekerti et al. (2007 : 9.6) mengemukakan bahwa :

Motorik halus adalah berbagai gerakan yang melibatkan fungsi jari jemari,seperti melipat, menggunting, menjahit, menganyam, menari, menganyam dan menggambar sedangakan motorik kasar adalah berbagai gerakan yang melibatkan otot-otot besar dan sendi-sendi, seperti meloncat, memanjat dan melepar.

Menurut Gesell dan Ames (1940) serta Illingsworth (1983) dalam Suyanto (2005:50-51) menyebutkan perkembangan motorik pada anak mengikuti delapan pola umum sebagai berikut.

a. Continuity (bersifat kontinu), dimulai dari gerakan yang sederhana menuju ke yang lebih kompleks sejalan dengan bertambahnya usia anak.

b. Uniform sequence (memiliki pola tahanan yang sama), semua anak memiliki pola tahapan yang sama meskipun kecepatan tiap anak untuk mencapai tahapan tersebut berbeda.

c. Maturity (kematangan), dipengaruhi oleh perkembangan sel saraf. Sel saraf telah terbentuk saat anak lahir, tetapi proses mielinasinya masih terus berlangsung , sampai beberapa tahun kemudian.

d. Umum ke khusus, yaitu mulai dari gerak yang bersifat umum ke gerak yang bersifat khusus. Hal ini disebabkan karena otot-otot besar berkembang lebih dulu dibandingkan otot-otot halus.

e. Dimulai dari gerak refleks bawaan kearah gerak yang terkoordinasi.

f. Bersifat chepalo-caudal direction, artinya bagian yang mendekati kepala berkembang lebih dahulu dibanding bagian yang mendekati ekor. Otot pada leher berkembang lebih dahulu daripada otot kaki.

g. Bersifat proximo-distal, artinya bahwa bagian yang mendekati sumbu tubuh (tulang belakang) berkembang lebih dulu dari yang lebih jauh. Otot dan saraf lengan berkembang lebih dahulu daripada otot jari. Oleh karena itu anak TK menangkap bola dengan lengan bukan dengan jari.

h. Koordinasi bilateral menuju crosslateral, artinya bahwa koordinasi organ yang sama berkembang lebuh dulu sebelum bisa melakukan koordinasi organ bersilangan.

Kemampuan motorik merupakan salah satu komponen yang penting dalam pencapaian hasil pembelajaran keterampilan motorik, kemampuan motorik setiap individu pada umumnya tidak sama atau bervariasi. Ada beberapa faktor yang menentukan dan mempengaruhi hasil pembelajaran motorik antara lain pendekatan metode pembelajaran. Metode pembelajaran yang digunakan dalam proses belajar mengajar hendaknya sesuai dengan karakteristik dan perkembangan anak.

Selain metode pembelajaran, faktor internal dari anak juga mempengaruhi kemampuan motorik. Faktor internal setiap anak berbeda satu sama lainnya. Faktor 
internal yang mempengaruhi kemampuan motorik seperti fisik, mental, sosial, emosional, intelegensi dan kemampuan lainnya. Selain itu faktor situasi dan kondisi pembelajaran juga memberikan kontribusi atas keberhasilan dan kemampuan motorik peserta didik.

Faktor-faktor lingkungan lainnya yang dapat memberikan sumbangan terhadap perkembangan motorik yaitu, kesehatan anak yang baik, pengendalian emosional, adanya kemandirian, kegiatan yang menyenangkan, adanya sosialisasi dengan teman sebaya. Faktor-faktor tersebut diharapkan dapat menjadi stimulus perkembangan motorik anak.

Baumgartner dalam bukunya mendefinisikan bahwa kemampuan motorik adalah kapasitas individu secara umum. Kapasitas individu merupakan kemampuan motorik yang terdiri dari : kecepatan (speed), kelincahan (agility), kekuatan (power), keseimbangan (balance), kelenturan (flexibility) dan koordinasi (coordination).

\section{Desain Pembelajaran Tari}

a. Eksplorasi

Berikut ini langkah-langkah dalam pembelajaran tari :

Pembelajaran tari perlu diberikan kepada anak agar dapat mengungkapkan orisinalitas gerak. Pengungkapan gerak melalui eksplorasi yaitu pengungkapan ide-ide gerak dan menuangkan kedalam ekspresi anak untuk mengembangkan kepribadian, kemampuan sosialisasi dan kreativitas. Dalam penelitian ini, eksplorasi diberikan kesempatan pada anak setelah guru memberikan contoh terlebih dahulu sehingga anak akan mudah menirukannya.

b. Improvisasi

Pembelajaran tari dilaksanakan tidak mengikat namun perlu diperkenalkan kepada anak melalui apresiasi dengan cara meberikan gambaran tentang gerak dasar tari untuk memberikan kesempatan dalam mengungkapkan ekspresi gerak sesuai dengan kemampuannya. Improvisasi yang dilakukan anak berlangsung secara alami sesuai kemampuan dalam menginterpretasikan dengan pemahaman anak. Melalui Improvisasi guru akan memahami tingkat kemampuan anak dalam menginterpretasikan pemahaman tentang gerak yang dimiliki anak. Seyogyanya guru memberikan kebebasan kepada anak dalam bergerak.

c. Penyusunan atau penggabungan gerak

Dengan menari anak diharapkan dapat berapresiasi dan memberikan kesempatan untuk mengembangkan motorik dengan pengalaman mengungkapkan ekspresi gerak untuk meningkatkan kemampuannya. Gerak yang dilakukan berdasarkan eksplorasi dan improvisasi serta gerak peniruan. Penyusunan gerak sangat dibutuhkan dalam menari agar ada patokan atau standar dalam pembelajaran menari, sehingga memudahkan guru dan anak dalam bergerak selanjutnya.

Ada beberapa hal yang menjadikan stimulus sehingga dapat melakukan gerakan tari seperti yang diungkapkan Cahyono, (2004:6.3) diantaranya :

a. Rangsang visual 
Rangsang visual muncul karena objek gambar, warna, wujud, sehingga dapat bereksplorasi berdasarkan pengamatan secara langsung.

b. Rangsang auditif/dengar

Rangsang dengar muncul berdasarkan musi yang muncul, sehingga melalui musi akan memperoleh inspirasi untuk bergerak.

c. Rangsang gagasan/ide

Rangsang ide muncul berdasaran kapasitas dan kemampuan dari seorang piñata tari, yaitu sebagai motivator untuk berkarya.

d. Rangsang kinestetik

Rangsang kinestetik muncul berdasarkan gerak itu sendiri berdasarkan fungsi kinestetik itu.

\section{Fungsi Iringan Tari}

Musik atau iringan sangat pendidikan fungsinya dalam keberlangsungan suatu tarian. Musik atau iringan tari terbagi menjadi dua, yaitu musik internal dan musik eksternal. Musik internal yaitu musik yang ditimbulkan atau dihasilkan dari diri si penari, seperti : tepukan tangan, nyanyian, hentakan tangan, petikan jari dan sebagainya. Sedangkan musik eksternal yaitu musik yang dihasilkan atau ditimbulkan dari luar diri si penari, seperti : musik gamelan atau jenis alat musik lainnya.

Iringan musik dan tari merupakan pasangan yang tidak dapat dipisahkan satu dengan yang lainnya. Keduanya berasal dari sumber yang sama, yaitu dorongan atau naluri ritmis (Margareth N.H. Doubler, 1985:156)

Musik selain menjadi pengiring tarian juga sebagai penguat tarian dan pendukung suasana tarian. Sesuai dengan karakteristik anak usia dini maka jenis musik atau iringan bagi anak usia dini harus lebih dinamis, agar menimbulkan kesan riang dan tidak membosankan. Musik pengiring tarian tidak selalu menggunakan alat musik gamelan, melainkan bisa menggunakan alat-alat musik sederhana yang ada di lingkungan sekitar, dan tentunya dituntut adanya kreativitas dari seorang instruktur.

\section{Penutup}

Pendidikan anak usia dini merupakan pendidikan yang paling mendasar guna mempersiapkan pendidikan berikutnya. Proses pembelajaran pada anak usia dini selalu mengupayakan konsep belajar yang bermakna dan menyenangkan. Namun pada kenyataannya proses pembelajaran pada anak usia dini selalu menekankan pada aspek kognitif saja, sehingga aspek-aspek lainnya yang akan membentuk kepribadian anak yang mandiri dan berkembangnya aspek motorik sering dikesampingkan. Pendidikan seni melalui pembelajaran tari merupakan jembatan bagi berkembangnya motorik anak baik motorik kasar dan motorik halus. Ada beberapa stimulus sehingga anak dapat melakukan gerakan tari, seperti : rangsang visual, rangsang auditif, rangsang kinestetik, dan rangsang ide.

Perkembangan motorik anak setiap anak berbeda tergantung tingkat kematangan anak tersebut. Ada beberapa yang dapat mempengaruhi perkembangan 
motorik anak, selain faktor lingkungan, kesehatan anak yang baik, pengendalian emosional, adanya kemandirian, kegiatan yang menyenangkan, adanya sosialisasi dengan teman sebaya hal tersebut merupakan stimulus bagi perkembangan motorik anak.

\section{DAFTAR PUSTAKA}

Atmadibrata, Enoch. 1986“Drama Tari sebagai Satu Bentuk Karya Seni”, dalam Pengetahuan Elemen Tari dan Beberapa Masalah Tari. Jakarta : Direktorat Kesenian,.

Barrow, M. Harold. Rosemery McGee. 1976.A Practical Approach to Measurement in Physical Education. Philadelphia, Lea and Fiberger,

Bredekamp. Sue. 1992Developmentally Appropriate Pracitice in Early Childhood Programs Serving Children From Birth Through Age 8 .Washington:NAEYC,

Cahyono, Agus. 2004.Materi dan Pembelajaran Kertakes. Jakarta: Universitas Terbuka,

Cokrohamidjyo, F.X. Sutopo. 1986.Pengetahuan Elementer Tari dan Beberapa Masalah Tari. Jakarta : Direktorat Kesenian,

Depdiknas, 2004. Kurikulum 2004. Jakarta : Depdiknas,

Durban, Ardjo. Irawati. 2008.Kawit Teknik Gerak dan Tari Dasar Sunda. Bandung:Pusbitari Press,

Doubler, Margareth N.H. 1985.Dance A Creative Art Experience. TerjemahanKumorohadi. Surabaya : STK Wilwatikta.

Gallahue, David L and John C. Ozmun. 1998.Undestanding Motor Development. USA : The McGraw-Hill Companinies,

Gardner, Howard. 1983.Multiple Intelligences : The Theory in Practice. New York : Harper Collins,

Hidayat, Robby. 2006.“Seni Tari (Pengetahuan Teori dan Praktek Seni Tari Bagi Guru). Malang:Jurusan Seni dan Desain Fakultas Sastra Universitas Negeri Malang,

Humphrey, Doris. Seni Menata Tari. Terjemahan Sal Murgiyanto. Jakarta:DKJ, 1983.

Hurlock, B. Elizabeth. 1991Perkembangan Anak. Jakarta:Erlangga,.

Jazuli, M. 1994.Telaah Teoretis Seni Tari. Semarang:IKIP Press,

.......... , 2008. Paradigma Kontekstual Pendidikan Seni, Surabaya:Unesa University Press

John Martin. 1989.The Modern Dance. New York:Princeton Book Company,

Kussudiarjo, Bagong. 1981.Tentang Tari. Yogyakarta:Nur Cahya,

Liang Gie, The. 2004.Filsafat Keindahan. Yogyakarta : PUBIB,

Margareth, H'Doubler. 1970.Education Through Dance”. The Dance Experince Readings in Dance Apreciation. Ed Myron Howard Nadel and Constance Gwen Nadel. New York, Washington, London : Preacer Publishers,

Martin, John. 1989.The Modern Dance. New York: Princeton Book Company, 
Montessori, Maria. 2008.The Absorbent Mind. Penerjemah Dariyanto. Yogyakarta:Pustaka Pelajar,

Munandar, S.C.Utami. 1993.Memadu dan Memupuk Bakat:Suatu tantangan bagi Pendidikan di Indonesia. Jakarta:UI Pess,

Murgiyanto, Sal., 1983.Koreografi. Jakarta:Dirjen Pendidikan Dasar dan Menengah ...1986.."Komposisi Tari,” dalam Pengetahuan Elemen Tari dan Beberapa Masalah Tari. Jakarta : Direktorat Kesenian,

Mutiah, Diana. 2010.Psikologi Bermain Anak Usia Dini. Jakarta:Kencana Prenada Media Group,

Nasution, S., 1997.Metode Penelitian Naturalistik Kualitatif . Bandung: Tarsito,

Pekerti, W, et al. 2007.Metode Pengembangan Seni. Jakarta: Universitas Terbuka.

Pugh, Brenda. McCutchen. 2006.Teaching Dance as Art in Education.United States:Human Kinetics,

Purnomo, E. 1993.Fungsi tari dalam dunia pendidikan anak usia prasekolah, majalah pendidikan gelora. Jakarta:Grasindo,

Richard, A. Schmidt. Motor Learning and Perfonmance from Principles to Practice Champaign, Illinois:Human Kinetics Books,

Robert, N. Singer. 1980Motor Learning and Human Performance, an Application to Motor Skill and Movement Behavior.(New York, Mc Millan:Company Publishers,

Rohidi, T. Rohendi., 2000.Kesenian dalam Pendekatan Kebudayaan, Bandung : STISI Bandung,

Rachmi, Teti. 2004.Materi dan Pembelajaran Kertakes. Jakarta: Universitas Terbuka, Rusliana, Iyus. Seni Tari Untuk KPG. Jakarta:PT Dharma Karsa Utama, 1983/1984.

Samsudin.2008. Pembelajaran Motorik Di Taman Kanak-Kanak. Jakarta: Litera Predana Media Group.

Smith, Jacqueline. 1985.Dance Composition: A Practical Guide for Tacher. Terjemahan Ben Suharto. Yogyakarta:Ikalasari,

Soedarso. 1980.Tinjauan Seni. Yogyakarta : Suku Dayar Sana,

Soedarsono, 1972.Jawa dan Bali: Dua Pusat Perkembangan Dramatari di Indonesia, Gadjah Mada University Press,

...........1986.."Pengantar Pengetahuan dan Komposisi Tari" Pengetahuan Elemen Tari dan Beberapa Masalah Tari. Jakarta : Direktorat Kesenian,

Solehudin, 2000.Konsep Dasar Pendidikan Prasekolah. Bandung: FIP UPI,

Sujiono, B. 2007.Metode Pengembangan Fisik. Jakarta: Universitas terbuka,

Susanne K. Langer1970.. "Virtual Power" The Dance Experince Readings in Dance Appreciation. Ed. Myron Howard Nadel and Constance Gwen Nadel. New York, Washington, London : Preacer Publishers,

Susanto, Ahmad. 2011.Perkembangan Anak Usia Dini Pengantar dalam Berbagai Aspeknya. Jakarta:Kencana Prenada Media Group,

Sutopo, F.X., 1986.Pengetahuan Elementer Tari dan Beberapa Masalah Tari, Direktorat Kesenian Depdikbud, Jakarta,

Suyanto, Slamet. 2005.Dasar-Dasar Pendidikan Anak Usia Dini. Jakarta:Hikayat. 
Undang-Undang RI No. 20 Tahun 2003 tentang : Sistem Pendidikan Nasional/SISDIKNAS. Jakarta:BP. Cipta Jaya.

Yeti, Erlinda. 2011.Pengaruh Model Pembelajaran dan Kemampuan Gerak Tari Terhadap Kecerdasan Emosional Anak Usia Dini. (eksperimen pada siswa SDSN 04 Ujung Menteng Jakarta Timur) Disertasi : Jakarta : Universitas Negeri Jakarta. 